Журнал«Герспективитаінноваціїнаукиљ

(Серія«Гедагогіка», Серія«Гцихологія», Серія«Медицинв»

№2(7) 2022

УДК 376.091.21

https://doi.org/10.52058/2786-4952-2022-2(7)-324-332

Калініченко Ірина Олександрівна кандидат педагогічних наук, завідувачка кафедри педагогічної майстерності та інклюзивної освіти, Полтавський обласний інститут післядипломної педагогічної освіти ім. М. В. Остроградського, вул. Соборності, 64ж, м. Полтава, 36029, тел.: (095) 889-03-33, https://orcid.org/0000-0003-3079-270X

\title{
ДІЯЛЬНІСТЬ ІНКЛЮЗИВНО-РЕСУРСНИХ ЦЕНТРІВ ЩОДО ПІДТРИМКИ ДІТЕЙ 3 ОСВІТНІМИ ТРУДНОЩАМИ
}

Анотація. Стаття має на меті дослідження та вивчення феномену «інклюзії» як суспільного-освітнього явища, що має місце в Україні. Інклюзивно-ресурсні центри (далі - ІРЦ), в свою чергу, є механізмом забезпечення конституційних прав та потреб дітей з особливими освітніми потребами.

Зазначений симбіоз утворює систему - «інклюзивне суспільство» або «інклюзивне освітнє середовище». Як відомо, останнє ототожнюється із повноцінною залученістю у процес соціалізації суспільства. Тобто, кожна дитина $\epsilon$ активною персоналією. У свою чергу, останнє можливо лише у випадку визнання іiі освітніх потреб, бажань та бар'єрів 3 якими вона стикається. Інклюзія - спосіб створити умови для розвитку на засадах рівності та поваги до людських прав незалежно від похідних обставин.

Таким чином, говоримо про певну стилістичну систему інклюзії, обрану Україною в умовах, в тому числі, гуманізації та соціалізації суспільства (громадський феномен) та Євроінтеграції (політико-правовий феномен).

Інклюзивно-ресурсні центри працюють задля дотримання концепту допомоги особливим категоріям дітей на засадах, встановлених Міністерством освіти і науки України (МОН). Саме $\mathrm{MOH}$ регламентує право на звернення до ІРЦ, алгоритм допомоги особам з особливими потребами у віці від 0 років та можливість проходження дитиною комплексної психолого-педагогічної оцінки розвитку в ІРЦ.

ІРЦ де-факто, є засобом організації освітнього процесу для дитини 3 особливими освітніми потребами, саме рекомендації фахівців ІРЦ ; дозволяють педагогам зрозуміти, як порушення впливають на участь дитини в шкільному житті, і що потрібно зробити для мінімізації цього впливу, та як орієнтуватися на сильні сторони дитини, а не ii проблеми. Дане поняття - збірне, адже включає аспект ставлення до дитини та налагодження контакту (концепту взаємодії) із дитиною з особливими освітніми потребами. За даним підходом, особлива освітня потреба дитини, іншими словами освітні труднощі, це труднощі у навчанні, які впливають на процес здобуття освіти та результати навчання здобувачів освіти відповідного року навчання. 
Інклюзія як феномен трансформації культури, політики та практики у школах таким чином, щоб враховувати різноманітні потреби окремих учнів, а також зобов'язання усувати будь-які перешкоди, що заважають такій можливості. ІРЦ працює на основі індивідуального вивчення функціонування особи, що є результатом складної взаємодії між станом здоров'я, а також факторами навколишнього середовища і особистісними факторами.

Ключові слова: інклюзія, інклюзивно-ресурсні центри, інклюзивне суспільство, освітні труднощі, особливі освітні потреби, інклюзивне освітне середовище.

Kalinichenko Iryna Oleksandrivna Candidate of Pedagogical Sciences, Head of the Department of Pedagogical Skills and Inclusive Education of Poltava Regional Institute of Postgraduate Pedagogical Education named after M.V. Ostrogradsky, Sobornosti St., 64, Poltava, 36029, tel.: (095) 889-03-33, https://orcid.org/0000-0003-3079-270X

\section{ACTIVITIES OF INCLUSIVE RESOURCE CENTERS FOR SUPPORT OF CHILDREN WITH EDUCATIONAL DIFFICULTIES}

Abstract. The article aims to study and study the phenomenon of "inclusion" as a social and educational phenomenon that takes place in Ukraine. Inclusive Resource Centers (IRCs), in turn, are a mechanism for ensuring the constitutional rights and needs of children with special educational needs.

This symbiosis forms a system - "inclusive society" or "inclusive educational environment". As you know, the latter is identified with full involvement in the process of socialization of society. That is, each child is an active person. In turn, the latter is possible only if the educational needs, desires and barriers she faces are recognized. Inclusion is a way to create conditions for development based on equality and respect for human rights, regardless of the circumstances.

Thus, we are talking about a certain stylistic system of inclusion chosen by Ukraine in the conditions of, inter alia, humanization and socialization of society (social phenomenon) and European integration (political and legal phenomenon).

Inclusive resource centers work to comply with the concept of assistance to special categories of children on the basis established by the Ministry of Education and Science of Ukraine (MES). It is the Ministry of Education and Science that regulates the right to apply to the IRC, the algorithm of assistance to persons with special needs from the age of 0 and the possibility for a child to undergo a comprehensive psychological and pedagogical assessment of development in the IRC.

The IRC de facto is a means of organizing the educational process for a child with special educational needs, namely the recommendations of the IRC specialists; allow educators to understand how disruptions affect a child's participation in school life, and what needs to be done to minimize that impact, and how to focus on the child's strengths rather than the child's problems. This concept is collective, because it 
includes the aspect of attitude to the child and establishing contact (concept of interaction) with a child with special educational needs. According to this approach, the special educational needs of the child, in other words, educational difficulties, are learning difficulties that affect the educational process and the learning outcomes of students in the relevant year of study.

Inclusion as a phenomenon of transformation of culture, policies and practices in schools in such a way as to take into account the diverse needs of individual students, as well as the obligation to remove any obstacles to such opportunities. The IRC works on the basis of an individual study of a person's functioning, which is the result of a complex interaction between health status, as well as environmental and personal factors.

Keywords: inclusion, inclusive resource centers, inclusive society, educational difficulties, special educational needs, inclusive educational environment.

Постановка проблеми. Інклюзивне навчання - виклик для вітчизняної освітньо-виховної системи. До компетенції ІРЦ, як органу забезпечення інклюзивної політики, відноситься: проведення оцінки розвитку дитини (психологічний та педагогічний аспекти - комплексно); надання послуг психолого-педагогічного та корекційно-розвиткового характеру; кваліфікованосистемний «супровід» осіб з особливими освітніми потребами.

Водночас, виникають проблеми із визначенням предметної компетенції ІРЦ та запровадженням інклюзії на практиці. «Інклюзивне суспільство» в Україні на часі знаходиться на стадії розвитку - отже, визначення статусу «дитини 3 особливими освітніми потребами» потребує вдосконалення.

Окрім того, інклюзію необхідно розглядати як соціальне явище, що стандартизує такі поняття, як «соціалізація дитини», «рівність людських прав», «забезпечення теорії соціалізації» тощо. Недискримінація та неприпустимість булінгу — додаткові «наріжні камені», що формують надбудову інклюзивного освітнього середовища. Проблематика — взаємозв'язок, доповнюваність та замінність зазначених елементів за ситуаційної вимоги.

Аналіз останніх досліджень і публікацій. Інклюзивне освітнє середовище, а також діяльність специфічних ІРЦ - предмет науково-теоретичних та практично-прикладних досліджень вітчизняних та зарубіжних науковців.

Вагомий внесок у формування сучасного стану розробленості інклюзивновиховної проблематики внесли, зокрема, Ю. Найда, Н.Софій, С. Богданов, О. Заярнюк, Н. Коваленко, А. Колупаєва, С. Мельник, І. Ярмощук та інші.

Мета статті - дослідити, обгрунтувати та детально визначити діяльність ІРЦ щодо підтримки дітей з освітніми труднощами в Україні.

Виклад основного матеріалу. Діяльність інклюзивно-ресурсних центрів, в першу чергу, полягає у забезпеченні права на освіту дитини з особливими освітніми потребами на засадах законності, відкритості та рівності.

Державна політика України спрямовує діяльність ІРЦ на надання допомоги особам з особливими освітніми потребами у процесі здобуття ними дошкільної, загальної середньої, професійної (професвійно-технічної) освіти. Важлива 
нормативна презумпція - отримання психолого-педагогічних, корекційнорозвиткових, консультаційних послуг за місцем проживання (на ії виконання в Україні функціонує 673 IРЦ — дані за 01.01.2021р.).

Крім цього, звернення до ІРЦ - вільне та доступне для батьків дитини, починаючи 30 років. Заява батьків - виключна підстава до надання IРЦ відповідних комплексних послуг (таким чином, третя особа - вчитель, вихователь - можуть лише ініціювати звернення до ІРЦ за наявності згоди одного 3 батьків). У цей же час, звернення задля встановлення ключових аспектів розвитку дитини, з метою створення для неї сприятливих для навчання умов у закладі освіти, а також здійснення додаткових заходів, спрямованих на подолання ii освітніх труднощів, можливе за відсутності інвалідності або встановленого діагнозу. Контекстний аспект функціонування IPЦ добровільність звернення та презумпція ненадання послуг на примусових засадах.

Спектр послуг, що надаються IРЦ, є досить широким та розгалуженим. Варто виділяти наступні :здійснення комплексної психолого-педагогічної оцінки розвитку дитини; розроблення рекомендації щодо освітньої програми, надання психолого-педагогічних та корекційно-розвиткових послуг відповідно до потенційних можливостей дитини; надання психолого-педагогічних та корекційно-розвиткових послуг дітям 3 ООП, які навчаються у закладах дошкільної, загальної середньої освіти (не відвідують заклади освіти) та не отримують відповідної допомоги; участь в засіданнях команд психологопедагогічного супроводу дитини 3 ООП у закладах освіти; методологічна допомога педагогічним працівникам та батькам дітей. [1].

Доцільно відзначити, що доступність комплексної оцінки розвитку дитини у ІРЦ підтверджується можливістю вільно та без черг отримати консультацію у найближчому центрі за допомогою попередньо поданої онлайн-заявки у мережі Інтернет через портал АС«ІРЦ» [2].

Комплексна оцінка розвитку дитини здійснюється за різногалузевими підходами. Зокрема, дослідженню підлягає аспект фізичного розвитку дитини, іiі дрібної, великої моторики, здатності до зорово-моторного наслідування. Окрім цього, важливим $\epsilon$ аналіз мовленнєвих можливостей - як вербальних та невербальних навичок із наявними або відсутніми тимчасовими чи постійними труднощами. У ІРЦ також розглядають когнітивно-процесуальні моменти розвитку індивідуума : зокрема, здатність до пізнання через сприйняття, пам'ять, увагу та мисленнєво-уявну сферу. Наостанок, вивчається освітня діяльність дитини - щодо сформованості специфічних вмінь, знань, навичок та компетентностей дитини залежно від вікового цензу. В окремих випадках іде вивчення соціальної сфери риозвитку дитини.

Відповідно до Постанови КМУ від 21 липня 2021 р. № 765 «Про внесення змін до деяких постанов Кабінету Міністрів України щодо організації навчання осіб з особливими освітніми потребами» до процедури проведення комплексної психолого-педагогічної оцінки розвитку дитини включено безпосереднє спостереження за дитиною у закладі освіти, що дозволить визначити контекст соціальної адаптації дитини; комунікативні здатності у соціальних групах : 3 
Журнал«Герспективитаінновації наукиљ

(Серія«Гедагогіка», Серія«Гцихологія», Серія«Медицинв»

№2(7) 2022

однолітками та дорослими тощо.

Порядок та регулярність проведення комплексних оцінок розвитку дитини фахівцями ІРЦ може варіюватися або змінюватися. Так, підстави для проведення повторних комплексних психолого-педагогічних оцінок розвитку дитини є: перехід дитини з ООП із дитячого садка до школи; перехід дитини зі спеціального закладу освіти до іншого закладу; рекомендації команди психолого-педагогічного супроводу дитини з ООП щодо наявності успіхів або труднощів у засвоєнні дитиною освітньої програми.

У якості бонусної ітерації, МОН надає детальне роз'яснення щодо відмінностей між психолого-педагогічними (ППП) та корекційно-розвитковими послугами (КРП) як складовими частинами інклюзіі. Отже, психолого-педагогічні послуги надаються ІРЦ задля розвитку дитини з особливими освітніми потребами шляхом участі у індивідуальних / групових заняттях; корекційно-розвиткові послуги - покращення мовленнєвої, пізнавальної та соціально-комунікативної сфери розвитку дитини (індивідуальний та груповий характер).

При цьому, завданням ППП та КРП визначаються : формування персональної самостійності дитини 3 особливими освітніми потребами; розвиток саморегулятивних та особистісних навичок як детермінанта формування знань, вмінь та галузевих компетентностей.

Нормативно-правове забезпечення діяльності ІРЦ здійснюється шляхом виконання Постанови КМУ від 12.07.2017 р. № 545 (редакція від 21.07.2021р.) «Про затвердження Положення про інклюзивно-ресурсний центр». Оскільки дитина $з$ особливими освітніми потреби часто стикається зі складнощами у інтерпретації специфічного матеріалу, законодавчим актом було введено поняття «освітні труднощі» — як питання навчального процесу, що стосуються певного здобувача освіти конкретного року навчання [3].

Додатковим елементом на шляху до формування сталої структури IРЦ в Україні стало впровадження «безбар'єрності». Відтак, Кабінетом Міністрів України було внесено відповідні зміни до Постанови КМУ від 12.07.2017 р. № 545 (редакція від 21.07.2021 р.) «Про затвердження Положення про інклюзивно-ресурсний центр» та інших нормативних документів щодо інклюзивних центрів - у контексті розширення допомоги дітям з особливими потребами. До таких ініціатив можна віднести, в першу чергу, уточнення завдань галузевої діяльності ІРЦ та підвищення професійної компетенції працівників (фахівців) таких центрів. Задля більш предметної роботи ІРЦ більш конкретно типізовано освітні труднощі, а також - видалено норму щодо встановлення нижньої вікової межі для проведення оцінки потреб, знань, вмінь та навичок дитини з особливими освітніми потребами.

Крім того, наразі в Україні є чинним Розпорядження КМУ № 366-р від 14.04.2021 р. «Про схвалення Національної стратегії із створення безбар’єрного простору в Україні на період до 2030 року». Даним документом «безбар'єрність» визначено як стилістику державної політики, метою котрої є вільний доступ усіх верств населення до відповідних сфер життєдіяльності. 
Отже, на рівні сучасної державно-управлінської думки «інклюзія» ототожнюється із запровадженням гуманних, проєвропейських цінностей та стандартів. У рамках даної Стратегії здійснюється нагляд за дотриманням критеріїв безбар’єрності та інклюзивності ІРЦ [4].

Варто виділити основні принципи, на яких засновано діяльність ІРЦ. До них віднесено : повагу та розуміння дитини, iii індивідуальних особливостей; забезпечення першочергових інтересів дитини з особливими освітніми потребами; неприпустимість дискримінаційних порушень прав, свобод та інтересів дітей; забезпечення принципу конфіденційності; формування доступної освіти (послуги раннього втручання); міжвідомче співробітництво тощо.

Окрім того, вчений І. Ярмощук виділяє додаткові (субсидіарні) функції, які є застосовними для центрів інклюзивної освіти (а, отже, і для IРЦ). Так, навігаційна функція передбачає формування необхідного базису для батьків щодо реалізації дітьми освітніх та соціально-емоційних потреб; інформаційна - надання відповідної інформації щодо інклюзивного навчання батькам, педагогам, іншим особам; забезпечення прав — підтримка батьків та законних представників дитини 3 особливими освітніми потребами у контексті забезпечення іï права на доступну, безперешкодну та повноцінну освіту та соціалізацію [5].

На сторінці Асоціації Міст України (стаття - «Створюємо інклюзивноресурсні центри» від 08.02.2018 р.) продубльовано завдання центру, процес та алгоритм створення IPЦ, характеристики специфічних приміщень та штатні завдання ІРЦ тощо. Наприклад, площа ІРЦ повинна бути щонайменше 160 кв. м.; на території центру необхідно дотримуватись санітарно-будівельних державних стандартів; кімнати для надання послуг фахівцями ІРЦ «інклюзивним дітям» мають бути належним чином для цього пристосовані [6].

За загальним правилом, ІРЦ має у своєму розпорядженні галузевих фахівців зокрема, дефектологів, психологів, логопедів, сурдопедагогів, представників напряму «спеціальної освіти» тощо. Практичні психологи забезпечують варіант гідної комунікації між ІРЦ, батьками та дітьми, налагоджуючи процес взаємодії. Логічно зауважити, що інклюзивні послуги надаються на засадах «деформалізації» - тобто вітається нешаблонний, персоніфікований підхід до вирішення освітніх труднощів у конкретних випадках.

Базуючись на теоретико-прикладних дослідженнях, зокрема, А. Колупаєвої, варто виділити наступні принципи корекційної роботи, що підлягають застосуванню у закладах ІРЦ. Першочергово, мова йде про єдність діагностики й корекції; встановлення доброзичливої, довірливої, підтримуючої, оптимістичної атмосфери спілкування, емпатійне ставлення до дитини; проведення психокорекції у зоні найближчого розвитку; орієнтування корекції й навчання на індивідуальні темпи психічного розвитку; використання принципу "заміщаючого онтогенезу" - початок корекційної роботи 3 «точки» відхилення від ідеальної програми розвитку, відтворення усіх закономірностей останнього; врахування вікових та індивідуальних особливостей дитини; врахування структури дефекту конкретної дитини та особливостей іiі соціальної ситуації розвитку; спрямованість корекційної роботи "зверху донизу", тобто створення 
оптимальних умов для розвитку вищих психічних функцій, за рахунок яких будуть компенсовані недоліки елементарних психічних процесів тощо [7].

За загальним правилом, корекція розвитку дитини з особливими освітніми потребами має випереджувальний характер. Концептуальна спрямованість подібної програмної ініціативи - активне формування базових навичок на короткострокову перспективу відповідно до законів вікового розвитку i становлення індивідуальності. Задля реалізації даних приписів ІРЦ застосовують наступні підходи : урахування системності розвитку в корекційній практиці; урахування компенсаторних можливостей дитини та ставлення до власного дефекту зі створенням атмосфери оптимізму, довіри, прагнення досягнень у розвитку; факультативно — забезпечення позитивної мотивації до розвитку і самовдосконалення.

На Рис. 1 представлено ідеальну модель діяльності ІРЦ щодо підтримки дітей з освітніми труднощами в Україні.

Ставлення до дитини з особливими освітніми потребами : емпатія, розуміння, безбар'єрність
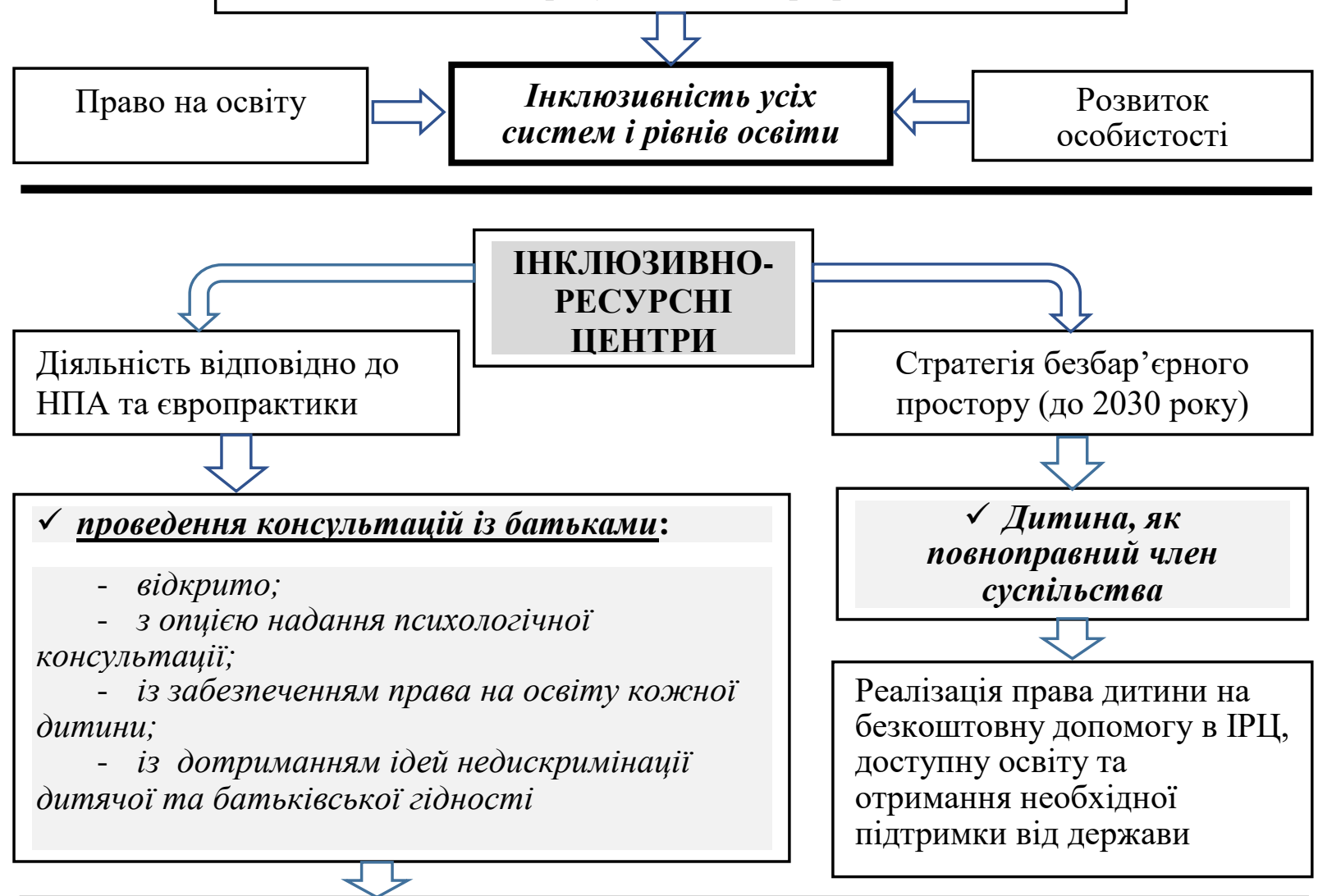

\begin{tabular}{|l|}
\hline Діяльність ІРЦ на наступних засадах : \\
єдність діагностики й корекції; \\
встановлення доброзичливої, довірливої, підтримуючої, оптимістичної атмосфери \\
$\frac{\text { спілкування, емпатійне ставлення до дитини; }}{\text { проведення психокорекції у зоні найближчого розвитку; }}$ \\
орієнтування корекції й навчання на індивідуальні темпи психічного розвитку; \\
спрямованість корекційної роботи "зверху донизу. \\
\hline
\end{tabular}

Puc. 1. Модель роботи ІРЦ задля забезпечення права дітей з особливими освітніми потребами на освіту 
Таким чином, функціонування ІРЦ - системний, предметний та впорядкований механізм, що має на меті охорону прав дитини та кореспондує приписам, що викладені у - Конституції України (зокрема, ст. 3, ст. 24, ст. 52, ст. 53 КУ).

Додатковим законодавчий базисом, котрому повинна відповідати діяльність ІРЦ, є наступні акти правотворчості : закон України «Про освіту» № 2145-VIII від 05.09.2017 р. (редакція від 21.11.2021 р.); закон України «Про повну загальну середню освіту» № 463-IX від 16.01 .2020 р. (редакція від 24.11 .2021 р.); закон України «Про дошкільну освіту» № 2628-III від 11.07.2001 р. (редакція від 01.01.2021 р.) тощо.

Висновки. Детальний та контекстний аналіз діяльності ІРЦ щодо підтримки дітей з освітніми труднощами в Україні дозволяє зробити наступні висновки. По-перше, нормативно-управлінське регулювання даного сегменту активно вдосконалюється: 3'являються галузеві нормативні документи (ПКМУ № 545, Розпорядження КМУ № 366-р, профільні «освітні» закони - зокрема, «Про повну загальну середню освіту» № 463-IX).

У той же час, наявна опція подання онлайн-заявки на консультацію до ІРЦ шляхом використання Інтернет-порталу АC «ІРЦ» Зазначений факт свідчення інформатизаційних, діджиталізаційних та глобалізаційних перетворень, що вірно сприймаються державою.

Наостанок, потрібно акцентувати увагу на демократичній місії IРЦ : забезпечення права на освіту дітей 3 особливими освітніми потребами із одночасною неприпустимістю її дискримінації (та, відповідно, членів її родини або законних представників).

\section{Лimepamypa:}

1. Інклюзивно - ресурсні центри : МОН // Офіційний веб-сайт // Режим доступу : https://mon.gov.ua/ua/dlya-batkiv/karta-irc-ta-zakladiv

2. Інтернет-портал «Україна. ІНКЛЮЗІЯ» : Система автоматизації роботи ІРЦ // Режим доступу : https://ircenter.gov.ua/

3. ПКМУ № 545 від 12.07.2017 р. (редакція від 21.07.2021 р.) «Про затвердження Положення про інклюзивно-ресурсний центр» // Відомості Верховної Ради // Режим доступу : https://zakon.rada.gov.ua/laws/show/545-2017-\%D0\%BF\#Text

4. Розпорядження КМУ № 366-p від 14.04.2021 p. «Про схвалення Національної стратегії із створення безбар'єрного простору в Україні на період до 2030 року» // Відомості Верховної Ради // Режим доступу : https://zakon.rada.gov.ua/laws/show/366-2021-\%D1\%80\#Text

5. Ярмощук I. Інклюзивне навчання в системі освіти // I. Ярмощук, 2009 // С. 24-28.

6. Асоціація Міст України : «Створюємо інклюзивно-ресурсні центри», стаття від 08.02.2018 p. // Режим доступу : https://auc.org.ua/novyna/stvoryuyemo-inklyuzyvno-resursni-centry

7. Колупаєва А.А. «Вступ до інклюзивної освіти» // А.А. Колупаєва, 2010. - 19 с.

8. Калініченко І. Місце інклюзивно-ресурсного центру в сучасному освітньому просторі/ I.Калініченко// Perspectives of world science and education. Abstracts of the 7th International scientific and practical conference. CPN Publishing Group. - Osaka, Japan. : CPN Publishing Group. - 2020. - Pp. 513-521. URL: https://sci-conf.com.ua . ISBN 978-4-9783419-8- 3

References:

1. Inkljuzivno - resursni centri : MON // Oficijnij veb-sajt // Rezhim dostupu : https://mon.gov.ua/ua/dlya-batkiv/karta-irc-ta-zakladiv 
2. Internet-portal «Ukraïna. INKLJuZIJa»: Sistema avtomatizaciï roboti IRC // Rezhim dostupu : https://ircenter.gov.ua/

3. PKMU № 545 vid 12.07.2017 r. (redakcija vid 21.07.2021 r.) «Pro zatverdzhennja Polozhennja pro inkljuzivno-resursnij centr»// Vidomosti Verhovnoï Radi // Rezhim dostupu : https://zakon.rada.gov.ua/laws/show/545-2017-\%D0\%BF\#Text

4. Rozporjadzhennja KMU № 366-r vid 14.04.2021 r. «Pro shvalennja Nacional'noï strategiï iz stvorennja bezbar'€rnogo prostoru v Ukraïni na period do 2030 roku» // Vidomosti Verhovnoï Radi // Rezhim dostupu : https://zakon.rada.gov.ua/laws/show/366-2021-\%D1\%80\#Text

5. Jarmoshhuk I. Inkljuzivne navchannja v sistemi osviti // I. Jarmoshhuk, 2009 // S. 24-28.

6. Asociacija Mist Ukraïni : «Stvorju€mo inkljuzivno-resursni centri», stattja vid 08.02.2018 r. // Rezhim dostupu : https://auc.org.ua/novyna/stvoryuyemo-inklyuzyvno-resursni-centry

7. Kolupa€va A.A. «Vstup do inkljuzivnoï osviti» // A.A. Kolupa€va, 2010. - 19 s.

8. Kalinichenko I. Misce inkljuzivno-resursnogo centru v suchasnomu osvitn'omu prostori / I.Kalinichenko// Perspectives of world science and education. Abstracts of the 7th International scientific and practical conference. CPN Publishing Group. - Osaka, Japan. : CPN Publishing Group. -2020. - Pp. 513-521. URL: https://sci-conf.com.ua . ISBN 978-4-9783419-8- 3 